\author{
ANETA GRABOWSKA \\ Uniwersytet Mikołaja Kopernika w Toruniu \\ anetagrabowska@vp.pl
}

\title{
Zakaz dyskryminacji w zatrudnieniu ze względu na niepełnosprawność
}

\author{
The prohibition of discrimination in employment on grounds of disability
}

Streszczenie. Artykuł jest próbą ukazania węzłowych zagadnień $\mathrm{z}$ zakresu problematyki dyskryminowania $\mathrm{W}$ zatrudnieniu ze względu na niepełnosprawność. W artykule zarysowano definicję pojęcia „dyskryminacja” oraz „niepełnosprawność”. Przedstawiono zakaz dyskryminacji w prawie międzynarodowym, wspólnotowym i krajowym. Ukazane zostało funkcjonowanie zakazu w procesie rekrutacji, w czasie zatrudnienia oraz przy rozwiązaniu umowy o pracę. Na koniec przedstawiono roszczenia przysługujące osobie dyskryminowanej.

Słowa kluczowe: dyskryminacja; niepełnosprawność; prawo do pracy.

\begin{abstract}
The article is an attempt to show the nodal questions on the issues of discrimination in employment on account of disability. Concepts "discrimination" and "disability" are sketched out in the article. Prohibition of discrimination in international law, community law and national law is presented. Functioning of the prohibition in the recruitment process, at the time of employment and in the termination of employment is showed. Finally, article presents claims which discriminated person have.
\end{abstract}

Keywords: discrimination; disability; right to work.

\section{Uwagi wprowadzające.}

Przepis art. 2 pkt 10 ustawy z dnia 27 sierpnia 1997 r. o rehabilitacji zawodowej i społecznej oraz zatrudnianiu osób niepełnosprawnych ${ }^{1}$ stanowi, że niepełnosprawność oznacza trwałą lub okresową niezdolność do wypełniania ról społecznych z powodu stałego lub długotrwałego naruszenia sprawności organizmu, w szczególności powodującą niezdolność do pracy. Niepełnosprawność nie musi oznaczać niezdolności do pracy w rozumieniu art. 12 ustawy z dnia 17 grudnia 1998 r. o emeryturach i rentach Funduszu Ubezpieczeń Społecznych ${ }^{2}$. Orzeczenie wydane przez powiatowe lub miejskie zespoły do spraw orzekania o niepełnosprawności nie jest traktowane na równi z orzeczeniem o niezdolności do pracy $^{3}$. Z kolei orzeczenie lekarza orzecznika Zakładu Ubezpieczeń

\footnotetext{
${ }^{1}$ Tekst jedn.: Dz. U. 2011 nr 127 poz. 721 ze zm.

${ }^{2}$ Tekst jedn.: Dz. U. 2013 poz. 1440 ze zm.

${ }^{3}$ Por. wyrok Sądu Apelacyjnego w Szczecinie z dnia 17 lipca 2013 r., III AUa 157/13, LEX nr 1438160.
} 
Społecznych (o niezdolności do pracy) jest traktowane na równi z orzeczeniem o niepełnosprawności ${ }^{4}$.

Zarówno prawo międzynarodowe ${ }^{5}$ jak i krajowe gwarantuje każdemu prawo do pracy. Nie powinniśmy odbierać tego prawa osobom niepełnosprawnym, ponieważ, jak twierdził Jan Paweł II, „Osoby niepełnosprawne w pełni są podmiotami ludzkimi z należnymi im wrodzonymi, świętymi i nienaruszalnymi prawami, które mimo ograniczeń i cierpień wpisanych w ich ciało i władze, stanowią jednak o szczególnym znaczeniu godności i wielkości człowieka"6.

Celem niniejszego opracowania jest przedstawienie uregulowań dotyczących zakazu dyskryminacji w zatrudnieniu ze względu na niepełnosprawność w systemie prawa międzynarodowego, wspólnotowego i krajowego oraz wyjaśnienie pojęć dyskryminacja I niepełnosprawność. Przedmiotem naukowej refleksji będzie działanie zakazu przed nawiązaniem stosunku pracy, $\mathrm{w}$ trakcie trwania stosunku pracy oraz przy rozwiązywaniu umowy o pracę.

\section{Pojęcie oraz rodzaje dyskryminacji}

Dyskryminacja (łac. discrimino - rozróżniam) polega na odmiennym traktowaniu różnych podmiotów znajdujących się w podobnej sytuacji ${ }^{7}$. Podstawą nierównego i niesprawiedliwego traktowania jest przynależność do określonych kategorii lub grup społecznych, a nie indywidualne cechy osobowe bądź zachowanie jednostek ${ }^{8}$. Jest działaniem celowym, długotrwały i powtarzalnym, ma ona na celu usunięcie konkretnych osób z pewnych miejsc, sfer życia społecznego. Tak definiuje się dyskryminację w psychologii społecznej. Zgodnie z kodeksem pracy przyczynami dyskryminacji są między innymi płeć, wiek, niepełnosprawność, rasa, religia, narodowość, przekonania polityczne, przynależność związkowa, pochodzenie etniczne, wyznanie, orientacja seksualna, a także zatrudnienie na czas określony lub nieokreślony albo w pełnym lub w niepełnym wymiarze czasu pracy. $\mathrm{W}$ ujęciu prawnym nierówne traktowanie nie zawsze musi oznaczać dyskryminację ${ }^{9}$, takie

\footnotetext{
${ }^{4}$ Art. 5 ustawy z dnia 27 sierpnia 1997r. o rehabilitacji zawodowej i społecznej oraz zatrudnianiu osób niepełnosprawnych (tekst jedn.: Dz. U. 2011 r. Nr 127; poz. 721 ze zm.). Szerzej zob. I. Radziwon, Orzekanie o niepetnosprawności oraz o jej stopniu, w: Zatrudnianie osób niepetnosprawnych. Regulacje prawne, red. A. Giedrewicz- Niewińska, M. Szabłowska- Juckiewicz, Warszawa 2014, s. 52-53.

${ }^{5}$ Por. np. art. 23 ust. 1 Powszechnej Deklaracji Praw Człowieka.

${ }^{6}$ Jan Paweł II, Laborem exercens. Tekst i komentarze, red. J. Gałkowski, Lublin 1986.

${ }^{7}$ Słownik języka polskiego PWN. T. 1, A-K, red. nauk. M. Szymczak, Warszawa 1993, s. 488.

${ }^{8}$ A. Winiarska, W. Klaus, Dyskryminacja i nierówne traktowanie, „Studia BAS” 2011, Nr 2, s. 9-40.

${ }^{9}$ Należy zwrócić uwagę na fakt, że w prawie wspólnotowym dąży się do ujednolicenia definicji dyskryminacji. Świadczy o tym fakt, że pkt 6 preaumbuły do dyrektywy nr 2002/73 expressis verbis odwołuje się do definicji zawartych w dyrektywach nr 2000/43 oraz 2000/78. Dążenie do wprowadzenia spójnej siatki pojęciowej w odniesieniu do równego traktowania podkreśla M. Matey-Tyrowicz, Zakaz dyskryminacji w zatrudnieniu
} 
taktowanie musi być jednak usprawiedliwione. W wyroku Trybunału Konstytucyjnego wymieniono kryteria na podstawie których można odstąpić od nakazu równego traktowania podmiotów podobnych ${ }^{10}$. Kryteria te muszą mieć charakter relewantny (racjonalnie uzasadniony), proporcjonalny (waga interesu, któremu ma służyć różnicowanie musi pozostawać w odpowiedniej proporcji do wagi interesów, które zostaną naruszone) oraz powinny pozostawać w jakimś związku z innymi wartościami, zasadami czy normami.

W literaturze wyróżnia się dyskryminację bezpośrednią oraz pośrednią. Dyskryminowanie bezpośrednie $^{11}$ osoby niepełnosprawnej polega na traktowaniu jej mniej korzystnie, niż traktuje się lub traktowałoby się osobę pełnosprawną w podobnej sytuacji. Może ona polegać na wypłacie niższego wynagrodzenia za pracę taką samą, jaką wykonuje osoba pełnosprawna, na nieuwzględnianiu osób niepełnosprawnych do awansu czy wreszcie na zwolnieniu $\mathrm{z}$ pracy $\mathrm{z}$ przyczyny powstania niepełnosprawności. Dyskryminację pośrednią $^{12}$ zdecydowanie trudniej zauważyć. Ma ona miejsce wtedy, gdy osoba niepełnosprawna na skutek pozornie neutralnego postanowienia, zastosowanego kryterium lub podjętego działania znajduje się lub mogłaby znajdować się w niekorzystnej sytuacji. Przykładem takiego kryterium jest przyznanie przez pracodawcę premii osobom pracującym powyżej 40 godzin tygodniowo, podczas gdy osoba niepełnosprawna może pracować maksymalnie 35 godzin tygodniowo, zgodnie z zaleceniem lekarza. Co należy zaznaczyć, dyskryminacja bezpośrednia polega na stosowaniu różnych zasad do podobnych sytuacji, a dyskryminacja pośrednia wynika $\mathrm{z}$ zastosowania tej samej zasady do różnych sytuacji. Dyskryminacja pośrednia nie będzie zakazana, jeżeli postanowienie, kryterium lub działanie jest obiektywnie uzasadnione ze względu na zgodny z prawem cel, który ma być osiągnięty, a środki służące osiągnięciu tego celu są właściwe i konieczne.

\section{Zakaz dyskryminacji w systemie prawa międzynarodowego, wspólnotowego}

\section{i krajowego}

Artykuł 2 Powszechnej Deklaracji Praw Człowieka zakazuje dyskryminacji z jakichkolwiek powodów, wśród przykładowych przyczyn nie wymieniono explicite niepełnosprawności. Jeżeli chodzi o dwie wiążące Polskę umowy międzynarodowe, Międzynarodowy Pakt Praw Obywatelskich i Politycznych z 16 grudnia 1966 r. ${ }^{13}$ oraz Międzynarodowy Pakt Praw

w prawie wspólnotowym, w: Prawo pracy a wyzwania XXI wieku: księga jubileuszowa Profesora Tadeusza Zielinskiego, red. M. Matey-Tyrowicz, L. Nowacki, B. Wagnar, Warszawa 2012, s. 596.

10 Wyrok Trybunału Konstytucyjnego $\mathrm{z}$ dnia 16 grudnia 1997 r., $\mathrm{K} \quad 8 / 97$, http://orka.sejm.gov.pl/proc3.nsf/opisy/173.htm (dostęp: 23.04.2015).

${ }^{11}$ Art. $18^{3 \mathrm{a}} \S 3$ k. p. Szerzej zob. Kodeks pracy. Komentarz, T. I, red. K. Jaśkowski, Warszawa 2014, s. 108-109.

${ }^{12}$ Art. $18^{3 \mathrm{a}} \$ 4$ k. p. Szerzej zob. Kodeks pracy. Komentarz, T. I, red. K. Jaśkowski, Warszawa 2014, s. 116-118.

${ }^{13}$ Dz. U. z 1977 r. Nr 38, poz. 167. 
Gospodarczych, Społecznych i Kulturalnych z 16 grudnia 1966 r. $^{14}$, sytuacja wygląda tak samo. W art. 2 ust. 2 obu Paktów ustanowiono zakaz dyskryminacji, ponownie explicite nie wymieniono wśród przyczyn niepełnosprawności, użyto natomiast zwrotu ,jakiekolwiek inne okoliczności”. Jako istotną należałoby wymienić również Konwencję $\mathrm{Nr} 111$ Międzynarodowej Organizacji Pracy, dotyczącą dyskryminacji w zakresie zatrudnienia i wykonywania zawodu ${ }^{15}$, przyjętą w Genewie z dnia 25 czerwca 1958 r. $^{16}$.

Najważniejszymi aktami prawa wspólnotowego ${ }^{17}$, które dotyczą zakazu dyskryminacji w zatrudnieniu ze względu na niepełnosprawność, są dyrektywa Rady 2000/78/WE z dnia 27 listopada 2000 r. ustanawiająca ogólne warunki ramowe w dziedzinie zatrudnienia i $\operatorname{pracy}^{18}$ oraz Karta Praw Podstawowych Unii Europejskiej. $\mathrm{W}$ artykule pierwszym wspomnianej dyrektywy zakazuje się dyskryminacji w zatrudnieniu m. in. z powodu niepełnosprawności. Bardzo istotny jest artykuł 5 dyrektywy 2000/78/ $\mathrm{WE}^{19}$, w którym mowa o racjonalnych usprawnieniach dla osób niepełnosprawnych. Zgodnie z tym przepisem pracodawca zobowiązany jest do podjęcia właściwych środków, z uwzględnieniem potrzeb konkretnej sytuacji, aby umożliwić osobie niepełnosprawnej dostęp do pracy, wykonywanie jej lub rozwój zawodowy bądź kształcenie, o ile środki te nie nakładają na pracodawcę nieproporcjonalnie wysokich obciążeń. Obciążenia będą nieproporcjonalne tylko wtedy, gdy w niewystarczającym stopniu zostaną zrekompensowane ze środków istniejących w ramach polityki prowadzonej przez dane Państwo Członkowskie na rzecz osób niepełnosprawnych. Jeżeli chodzi o Kartę Praw Podstawowych Unii Europejskiej, należałoby wspomnieć o dwóch szczególnie ważnych artykułach. Artykuł 21 zakazuje dyskryminacji m. in. ze względu na niepełnosprawność, natomiast artykuł 26 dotyczy prawa osób niepełnosprawnych do korzystania ze środków mających zapewnić im niezależność, integrację społeczną i zawodową oraz udział w życiu społeczności.

\footnotetext{
${ }^{14}$ Dz. U. z 1977 r. Nr 38, poz. 169.

15 Konwencja obowiązuje w Polsce w pełnym zakresie. MOP stworzyła aż trzy dokumenty dotyczące zatrudniania osób niepełnosprawnych. Wcześniej wspomnianą Konwencję poprzedzono Zaleceniem Nr 168, nie ma ono mocy wiążącej. Trzecim dokumentem jest „Kodeks postępowania. Zarządzanie niepełnosprawnością w miejscu pracy", również nie ma on mocy wiążącej.

16 Szerzej zob. M. Jankowska, Prawa osób niepetnosprawnych $w$ międzynarodowych aktach prawnych, http://www.pfron.org.pl/kn/poprzednie-numery/68,Prawa-osob-niepelnosprawnych-w-miedzynarodowychaktach-prawnych-The-rights-of-di.html (dostęp: 28.04.2015 r.).

${ }^{17}$ Szerzej zob. L. Florek, Europejskie prawo pracy, Warszawa 2007, s. 81-90.

${ }^{18}$ Dz. Urz. UE L Nr 303, str. 16.

${ }^{19}$ R. Whittle, The Framework Directive for equal treatment in employment and occupation: an analysis from diability rights prospective, http://shura.shu.ac.uk/706/1/fulltext.pdf (dostęp: 06.05.2015 r.)
} 
Konstytucja Rzeczypospolitej Polskiej w art. 32 ust. 2 wprowadza zakaz dyskryminacji w życiu politycznym, społecznym lub gospodarczym z jakiejkolwiek przyczyny. Jedną $\mathrm{z}$ podstawowych zasad prawa pracy jest zakaz dyskryminacji $\mathrm{w}$ zatrudnieniu, sformułowany $\mathrm{w}$ art. $11^{3} \mathrm{k.p.} .^{20}$. Obowiązek równego traktowania w zatrudnieniu wyraża art. $18^{3 \mathrm{a}}$ k.p. Kolejnym ważnym aktem jest ustawa $\mathrm{z}$ dnia 27 sierpnia 1997 r. o rehabilitacji zawodowej i społecznej oraz zatrudnianiu osób niepełnosprawnych ${ }^{21}$. Reguluje ona problematykę orzekania o niepełnosprawności, obowiązków i uprawnień pracodawców W związku z zatrudnianiem osób niepełnosprawnych, zakładów pracy chronionej, zakładów aktywności zawodowej oraz inne zagadnienia.

\section{Zakaz dyskryminacji oraz nakaz równego traktowania}

Artykuł $18^{3 \mathrm{a}} \S 2$ k. p. zawiera definicję równego traktowania w zatrudnieniu. To sformułowanie oznacza niedyskryminowanie w jakikolwiek sposób, bezpośrednio lub pośrednio. Bardzo często te dwie zasady są traktowane jednoznacznie, jednak nie zawsze tak jest $^{22}$. Nie każde nierówne traktowanie pracowników będzie dyskryminacją, a tylko takie, które będzie bezpodstawne i krzywdzące. Jak wskazuje się w literaturze, nierówne traktowanie z powodów innych niż kryteria dyskryminujące może stanowić naruszenie zasady równości praw pracowników, ale nie stanowić będzie naruszenia zakazu dyskryminacji ${ }^{23}$. Przykładowe przyczyny dyskryminacji wrażone są w art. $18^{3 \mathrm{a}} \S 1$ k.p. Odróżniać należy zasadę równego traktowania $\mathrm{w}$ zatrudnieniu wyrażoną $\mathrm{w}$ art. $11^{2} \mathrm{k}$.p. oraz zasadę niedyskryminacji wyrażoną $\mathrm{w}$ art. $11^{3}$ oraz art. $18^{3 \mathrm{a}} \mathrm{k}$.p.

\subsection{Zakaz dyskryminacji ze względu na niepełnosprawność na etapie nawiązania stosunku pracy}

W praktyce często spotkać można ogłoszenia o pracę zawierające kryteria dyskryminacyjne. Przykładowa teść takiego ogłoszenia: Zatrudnimy do pracy w sklepie z odzieżą kobietę, górna granica wieku 35 lat, petnosprawna ${ }^{24}$. Ogłoszenie jest przykładem dyskryminacji bezpośredniej. Z dyskryminacją możemy spotkać się również w trakcie rozmowy

${ }^{20}$ Szerzej zob. Z. Góral, O kodeksowym katalogu zasad indywidualnego prawa pracy, Warszawa 2011, s. $153-167$.

${ }^{21}$ Tekst jedn.: Dz. U. 2011 r. Nr 127, poz. 721 ze zm.

${ }^{22}$ A. Czyżewska, Zasada równego traktowania a zakaz dyskryminacji - w jaki sposób odpowiada pracodawca?, maj 2011, http://biuletyn.piszcz.pl/prawo-pracy/41-anna-czyewska/266-zasada-rownego-traktowania-a-zakazdyskryminacji-w-jaki-sposob-odpowiada-pracodawca137 (dostęp: 06.05 .2015 r.).

${ }^{23}$ Por. wyrok Sądu Najwyższego z dnia 2 października 2012 r., II PK 82/12, Orzecznictwo Sądów Polskich, Warszawa 2014, Zeszyt 11, s. 1494-1503 oraz H. Szewczyk, Glosa do wyroku SN z dnia 2 października 2012 r., II PK 82/12, s. 1503-1508.

${ }^{24}$ Por. wyrok Sądu Najwyższego z 24 marca 2000 r., I PKN 314/99, LEX nr 48110 • „Kandydat do pracy zgłaszający się na ofertę pracodawcy dyskryminującą ze względu na płeć, który nie został zatrudniony, może dochodzić odszkodowania $\mathrm{w}$ granicach tzw. ujemnego interesu na podstawie przepisów o czynach niedozwolonych (art. 415 kodeksu cywilnego)". 
kwalifikacyjnej. Dyskryminacja pośrednia może przykładowo polegać na tym, że pracodawca, nie chcąc zatrudnić osoby poruszającej się na wózku inwalidzkim, jako miejsce rozmowy kwalifikacyjnej wskaże pomieszczenie w wysokim budynku, w którym nie ma windy (pozornie neutralny wymóg) ${ }^{25}$. Wyjątkowo różnicowanie ze względu na niepełnosprawność jest dozwolone, ale pracodawca musi udowodnić w sposób obiektywny, że daną pracę może wykonywać jedynie osoba pełnoprawna (np. praca fizyczna na budowie). Za naruszenie zasady równego traktowania $\mathrm{w}$ zatrudnieniu uważa się różnicowanie przez pracodawcę sytuacji pracownika $\mathrm{z}$ powodu niepełnosprawności, którego skutkiem jest $\mathrm{w}$ szczególności odmowa nawiązania stosunku pracy ${ }^{26}$. Wcześniej wspomnianej zasady nie naruszają działania proporcjonalne do osiągnięcia zgodnego z prawem celu różnicowania sytuacji pracownika, polegające na niezatrudnianiu pracownika z powodu niepełnosprawności, jeżeli rodzaj pracy lub warunki jej wykonywania powodują, że pełnosprawność jest rzeczywistym i decydującym wymaganiem zawodowym stawianym pracownikowi. Kandydatowi do pracy, wobec którego pracodawca naruszył zasadę równego traktowania, przysługuje prawo do odszkodowania ${ }^{27}$, zgodnie z ustawą to prawo przysługuje „osobie” a nie tylko pracownikowi ${ }^{28}$.

\subsection{Dyskryminacja ze względu na niepelnosprawność w trakcie trwania stosunku pracy}

Dyskryminacja ze względu na niepełnosprawność w czasie zatrudnienia może polegać na niekorzystnym ukształtowaniu wynagrodzenia za pracę lub innych warunków zatrudnienia, pominięciu przy awansowaniu lub przyznawaniu innych świadczeń związanych z pracą, pominięciu przy typowaniu do udziału w szkoleniach podnoszących kwalifikacje zawodowe. Pracownicy mają takie same prawa $\mathrm{z}$ tytułu jednakowego wypełniania takich samych obowiązków $^{29}$. Osoby niepełnosprawne i pełnosprawne zatrudnione na tym samym stanowisku, wykonujące taką samą pracę, powinny być traktowane jednakowo ${ }^{30}$. Ich płaca powinna być taka sama, jeżeli praca wykonywana jest tak samo rzetelnie i sprawnie. Jednak w praktyce często wygląda to inaczej. Czasami same osoby niepełnosprawne zainteresowane

\footnotetext{
25 Por. wyrok Naczelnego Sądu Administracyjnego z 12 maja 2000 r., II SA 143/00, www.orzeczenia-nsa.pl (dostęp 06.05.2015), w którym za bezprawną uznano „uchwałę zarządu gminy zakazującą kierownikom gminnych jednostek organizacyjnych zatrudniania bez jego zgody emerytów i rencistów".

${ }^{26}$ Art. $18^{3 \mathrm{~b}} \S 1$ pkt. 1) k. p. Natomiast w art. $18^{3 \mathrm{~b}} \S 2 \mathrm{k}$. p. sformułowano tzw. „kontratypy dyskryminacji”. Szerzej zob. A. M. Świątkowski, Kodeks pracy. Komentarz, Warszawa 2012, s. 93-96.

${ }^{27}$ Problem ten będzie analizowany szerzej w części 7 niniejszego artykułu, zatytułowanej Roszczenia.

${ }^{28}$ Art. $18^{3 \mathrm{~d}}$ k. p. Kodeks pracy. Komentarz, pod red. A. Sobczyka, Warszawa 2014, s. 73.

${ }^{29}$ Art. $11^{2}$ k. p. Zasada równości w dziedzinie zatrudnienia jest konkretyzacją konstytucyjnej zasady równości wszystkich wobec prawa. Szerzej zob. M. Gersdorf, M. Raczkowski, K. Rączka, Kodeks pracy. Komentarz, Warszawa 2014, s. 63-66.

${ }^{30}$ Art. 78 §1 k. p. Pracodawca może różnicować wysokość wynagrodzenia pracowników w zależności od ilości i jakości świadczone pracy. Szerzej zob. A. M. Świątkowski, Kodeks pracy. Komentarz, Warszawa 2012, s. 433.
} 
są niższym wynagrodzeniem, z powodu obawy przed utratą świadczeń ${ }^{31}$. Pracownicy, jednakowo wykonujący swoje obowiązki, powinni mieć równe szanse przy awansie oraz równy dostęp do szkoleń, które wpływają na wartość pracownika na rynku pracy. Jeżeli powody określonych decyzji pracodawcy są niejasne, pracownik, który czuje się dyskryminowany, może wnieść do sądu pozew o odszkodowanie. Przykładowo, gdy pracodawca, poszukując osoby, którą chce awansować na stanowisko dyrektora, ma do wyboru dwie osoby, jedną niepełnosprawną a drugą pełnosprawną, w takiej sytuacji nie może wybrać drugiej osoby tylko z tego powodu, że jest pełnosprawna. Może natomiast ją wybrać, jeżeli kryterium decydującym będą kwalifikacje czy staż pracy.

\subsection{Dyskryminacja ze względu na niepelnosprawność przy rozwiązywaniu umów o pracę}

Niezgodne z prawem jest rozwiązanie umowy o pracę z powodu niepełnosprawności. Należy zaznaczyć, że pracownik, z którym pracodawca rozwiązał umowę o pracę wyłącznie z powodu choroby, nie jest objęty ochroną ustanowioną dzięki zakazowi dyskryminacji ze względu na niepełnosprawność ${ }^{32}$. Pracodawca, zanim zdecyduje się na rozwiązanie umowy o pracę, ma obowiązek wprowadzić racjonalne usprawnienia dla osób niepełnosprawnych. Niedokonanie niezbędnych racjonalnych usprawnień, o których mowa w art. 23a ust. 1 ustawy z dnia 27 sierpnia 1997 r. o rehabilitacji zawodowej i społecznej oraz zatrudnianiu osób niepełnosprawnych, uważa się za naruszenie zasady równego traktowania $\mathrm{w}$ zatrudnieniu $\mathrm{w}$ rozumieniu przepisów art. $18^{3 \mathrm{a}}$ k.p. Artykuł 23a ustawy o rehabilitacji zawodowej i społecznej oraz zatrudnianiu osób niepełnosprawnych należy interpretować w ten sposób, że przez przyjęcie właściwych, to znaczy skutecznych i praktycznych środków, w celu przystosowania miejsca pracy dla osób niepełnosprawnych, należy rozumieć nie tylko przystosowanie pomieszczeń lub wyposażenia, ale również czasu pracy i podziału obowiązków ${ }^{33}$. Pracodawca nie ma obowiązku przeprowadzania zmian, jeżeli skutkowałoby to nałożeniem na niego nieproporcjonalnie wysokich obciążeń ${ }^{34}, \mathrm{z}$ zastrzeżeniem art. 23a ust. 2 wcześniej wspomnianej ustawy. Niepodjęcie działań, a jedynie samo stwierdzenie, że są one zbyt obciążające, nie wyczerpuje działań przewidzianych w art. 23a ustawy. Pracodawca powinien przynajmniej oszacować koszt takich zmian, może również

\footnotetext{
31 Jeżeli z zawiadomienia o wysokości przychodu, jaki zamierza osiągać emeryt lub rencista wynika, że przychód ten będzie osiągany w kwocie: przekraczającej 70\% przeciętnego miesięcznego wynagrodzenia, nie wyższej jednak niż 130\% tego wynagrodzenia, oddział ZUS wyda decyzję o zmniejszeniu wysokości świadczenia.

${ }^{32}$ Por. wyrok Europejskiego Trybunału Sprawiedliwości z dnia 11 lipca 2006 r. C-13/05, LEX nr 226783.

${ }^{33}$ Por wyrok Sądu Najwyższego z dnia 12 listopada 2014 r. I PK 74/14, LEX nr 1567458.

34 Szerzej na ten temat: M. Latos-Miłkowska, Ochrona trwałości stosunku pracy pracowników niepetnosprawnych i opiekunów osób niepetnosprawnych, w: Zatrudnianie osób niepetnosprawnych. Regulacje prawne, red. A. Giedrewicz- Niewińska, M. Szabłowska- Juckiewicz, Warszawa 2014, s. 257-265.
} 
wystąpić o sfinansowanie działań ze środków publicznych. Odmowa sfinansowania pozwala pracodawcy stwierdzić, że wymagane działania są nadmiernie obciążające. Nie będzie postępowaniem dyskryminującym zachowanie pracodawcy, który wprowadzi racjonalne usprawnienia i rozwiąże umowę o pracę $\mathrm{z}$ osobą niepełnosprawną $\mathrm{z}$ powodu braku kompetencji, zdolności, dyspozycyjności ${ }^{35} \mathrm{w}$ zakresie wykonywania najważniejszych czynności na zajmowanym przez siebie stanowisku. Niewykonanie przez pracodawcę obowiązków wynikających $\mathrm{z}$ art. 23a ustawy o zatrudnianiu i rehabilitacji osób niepełnosprawnych zostało przez ustawodawcę expressis verbis uznane za naruszenie zasady równego traktowania. Należy również zwrócić uwagę na art. 14 ustawy o rehabilitacji zawodowej i społecznej oraz zatrudnianiu osób niepełnosprawnych. Pracodawca, zanim zdecyduje się na rozwiązanie umowy o pracę, jest zobowiązany do wydzielenia lub zorganizowania odpowiedniego stanowiska pracy z podstawowym zapleczem socjalnym dla osoby zatrudnionej, która w wyniku wypadku przy pracy lub choroby zawodowej utraciła zdolność do pracy na dotychczasowym stanowisku. Jeżeli pracodawca nie wywiąże się z obowiązku i rozwiąże umowę o pracę, będzie musiał dokonać wpłaty na Państwowy Fundusz Rehabilitacji Osób Niepełnosprawnych ${ }^{36}$, co nie chroni przed ewentualnymi roszczeniami, których dochodzić może dyskryminowany pracownik.

\section{Rozwiązanie stosunku pracy $z$ pracownikiem wychowującym dziecko} niepelnosprawne (tzw. dyskryminacja przez asocjację)

Problem rozwiązania stosunku pracy $\mathrm{z}$ pracownikiem wychowującym dziecko niepełnosprawne był przedmiotem analizy w wyroku Europejskiego Trybunału Sprawiedliwości z dnia 17 lipca 2008 r. w sprawie S. Coleman przeciwko Attridge Law i Steve'owi Law ${ }^{37}$. Employment Tribunal wniósł o rozstrzygnięcie pytania prejudycjalnego, stan faktyczny nie był jeszcze ostatecznie ustalony. Orzeczenie zostało wydane w oparciu o twierdzenia przedstawione przez stronę powodową - Panią Coleman. S. Coleman pracowała od 2001 r. w charakterze sekretarza prawnego. W 2002 r. urodziła syna, który cierpi na ataki bezdechu oraz wrodzoną wiotkość oskrzeli i krtani. Stan jej syna wymaga specjalistycznej i szczególnej opieki. Po powrocie z urlopu macierzyńskiego były pracodawca odmówił jej powrotu na stanowisko pracy, jakie zajmowała dotychczas. Były pracodawca odmówił również przyznania jej takiej samej elastyczności czasu pracy oraz takich samych warunków

\footnotetext{
35 Przykładowo zwolnienie $\mathrm{z}$ powodu niepełnoprawności, na skutek której została utracona zdolność do wykonywania zawodu prokuratora prokuratury rejonowej nie stanowi niedozwolonego aktu dyskryminacji. Szerzej zob. wyrok Sądu Najwyższego z dnia 12 kwietnia 2012 r., II PK 218/11, LEX nr 1313656.

${ }^{36}$ Art. 23 ustawy z dnia 27 sierpnia 1997 r. o rehabilitacji zawodowej i społecznej oraz zatrudnianiu osób niepełnosprawnych (tekst jedn.: Dz. U. z 2011 r. Nr 127 poz. 721 ze zm.).

${ }^{37}$ LEX nr 420939.
} 
pracy, z jakich korzystali inni pracownicy. Gdy występowała o dni wolne od pracy w celu sprawowania opieki nad dzieckiem, czyniono obraźliwe komentarze wobec niej i jej dziecka, gdy okazjonalnie spóźniała się do pracy z powodu problemów związanych z opieką nad dzieckiem, poinformowano ją, że zostanie zwolniona z pracy, jeżeli jeszcze raz się spóźni. Takie wydarzenia nie miały miejsca w analogicznych sytuacjach w stosunku do rodziców dzieci, które były pełnosprawne. Trybunał Sprawiedliwości dokonał wykładni dyrektywy Rady 2000/78/WE z dnia 27 listopada 2000 r. ustanawiającej ogólne warunki ramowe równego traktowania w zakresie zatrudnienia i pracy ${ }^{38}$, odpowiadając na pytanie, które brzmiało następująco: „Czy w ramach zakazu dyskryminacji ze względu na niepełnosprawność dyrektywa [2000/78] chroni przed bezpośrednią dyskryminacją i molestowaniem jedynie osoby, które same są niepełnosprawne?”. W sprawie Sonia Chacón Navas przeciwko Eurest Colectividades SA Trybunał wąsko zdefiniowano niepełnosprawność, jednak z takiej wykładni nie wynika, by zasada równego traktowania zdefiniowana $\mathrm{w}$ art. 2 ust. 1 tej dyrektywy oraz zakaz dyskryminacji bezpośredniej przewidziany w art. 2 ust. 2 lit. a) nie mogły znajdować zastosowania do sytuacji takiej jak opisana powyżej, jeśli niekorzystne traktowanie pracownika ma miejsce ze względu na niepełnosprawność jego dziecka, któremu pracownik ten zapewnia zasadniczą opiekę, jakiej wymaga stan dziecka. Zakaz dyskryminacji bezpośredniej, jaki przewiduje art. 1 oraz art. 2 ust. 1 i art. 2 ust. 2 lit. a) dyrektywy Rady 2000/78/WE nie ogranicza się tylko do osób, które same są niepełnosprawne. Zasadę równego traktowania w obszarze zatrudnienia i pracy, stosuje się nie do jednej kategorii określonych osób, lecz w zależności od przyczyn, o których mowa $\mathrm{w}$ art. 1 dyrektywy. Sprzeczne $\mathrm{z}$ zakazem dyskryminacji jest traktowanie przez pracodawcę pracownika, który sam nie jest niepełnosprawny, w sposób mniej przychylny, niż traktuje lub traktowałby innego pracownika w porównywalnej sytuacji i gdy wykazano, że mniej korzystne traktowanie tego pracownika związane jest z niepełnosprawnością bliskiej mu osoby, której zapewnia on zasadniczą opiekę.

\section{Roszczenia przysługujące pracownikom dyskryminowanym ze względu na niepełnosprawność}

Zaleca się rozwiązywanie sporów na drodze pozasądowej na przykład poprzez mediację. Jeżeli jednak nie daje ona efektów, należy wytoczyć powództwo przeciwko pracodawcy o roszczenie za naruszenie zasady równego traktowania. Zgodnie z art. $18^{3 \mathrm{~d}} \mathrm{k}$. p. pracownik

\footnotetext{
${ }^{38}$ Dz. Urz. UE L Nr 303, str. 16.
} 
ma prawo do odszkodowania ${ }^{39}$, przyjmuje się, że obejmuje ono odszkodowanie za szkodę i zadośćuczynienie za krzywdę. Wysokość odszkodowania jest pozostawiona uznaniu sądu. Minimalna wysokość odszkodowania jest równa minimalnemu miesięcznemu wynagrodzeniu za pracę, maksymalna nie została określona. $\mathrm{W}$ art. $18^{3 \mathrm{~d}} \mathrm{k}$. p. nie uregulowano przesłanek, jakimi powinien kierować się sąd orzekający o wysokości należnego odszkodowania. Wysokość odszkodowania zależeć będzie od rodzaju i stopnia, w jakim pracodawca naruszył swoje obowiązki w zakresie równego taktowania $w$ zatrudnieniu ${ }^{40}$. Poza tym, gdy dyskryminacja łączy się $\mathrm{z}$ naruszeniem dóbr osobistych, dochodzić można roszczeń za naruszenie dóbr osobistych ${ }^{41}$, na przykład o zaniechania działania dyskryminującego, o dopełnienie czynności potrzebnych do usunięcia skutków naruszenia. Obok tego, W zależności od okoliczności, dochodzić możemy innych roszczeń: odszkodowania za bezzasadne wypowiedzenie umowy o pracę, o sprostowanie świadectwa pracy. Roszczenia ze stosunku pracy ulegają przedawnieniu z upływem 3 lat od dnia, w którym roszczenie stało się wymagalne ${ }^{42}$. Termin trzech lat biegnie od dnia, w którym ujawniła się szkoda lub krzywda w związku z dyskryminacją, może to nastąpić przed nawiązaniem stosunku pracy,

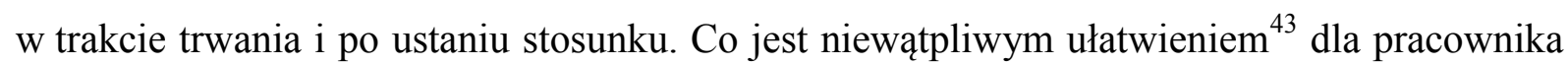
w czasie procesu, musi on jedynie uprawdopodobnić naruszenie zasady równego traktowania, a pracodawca musi wykazać, że kierował się obiektywnymi powodami ${ }^{44}$. Zgodnie z art. 6 k.c. ciężar udowodnienia faktu spoczywa na osobie, która $z$ tego faktu wywodzi skutki prawne, a więc to pracownik musiałby wykazać naruszenie zasady równego traktowania. Jednak kodeks pracy w art. $18^{3 \mathrm{~b}} \S 1$ zobowiązuje pracownika jedynie do wykazania faktu odmiennego ukształtowania jego sytuacji ${ }^{45}$.

\footnotetext{
${ }^{39}$ Według A. M. Świątkowskiego odszkodowanie stanowi jedyną sankcję, jaka może być zastosowana wobec pracodawcy dyskryminującego pracowników (A. M. Świątkowski, Kodeks pracy. Komentarz, Warszawa 2014, s. 100). Zdaniem K. Rączki odszkodowanie nie jest jedynym środkiem ochrony prawnej, przykładowo skorzystanie $\mathrm{z}$ tej sankcji nie wyklucza prawa do rozwiązania umowy o pracę z powodu ciężkiego naruszenia przez pracodawcę podstawowych obowiązków (K. Rączka, w: Kodeks pracy. Komentarz, Warszawa 2012, s. 104-105).

${ }^{40}$ M. T. Romer, Kodeks pracy. Komentarz, Warszawa 2012, s. 172-174.

${ }^{41}$ Art. 23, 24, 448 k. c.

${ }^{42}$ Art. 291 §1 k. p. Zgodnie z poglądem wyrażonym przez Sąd Najwyższy w wyroku z dnia 26 marca 2002 r., I PKN 57/01, LEX 563989, do przedawnienia roszczeń pracownika o naprawienie szkody wyrządzonej mu przez pracodawcę, których podstawę materialnoprawną stanowią przepisy kodeksu cywilnego o odpowiedzialności deliktowej, stosuje się art. $422 \S 1$ k. c. (obecnie $442^{1}$ k. c.).

${ }^{43}$ Wyrok SN z dnia 4 stycznia 2008 r., I PK 188/07, LEX nr 442864.

${ }^{44}$ Art. $18^{3 b} \S 1$ k. p. Szerzej zob. Kodeks pracy. Komentarz, T. I, red. K. Jaśkowski, Warszawa 2014.

45 A.M. Świątkowski, Kodeks pracy. Komentarz, Warszawa 2012, s. 86-87 oraz M. Gersdorf, K. Rączka, M. Raczkowski, Kodeks pracy. Komentarz, Warszawa 2014, s. 95.
} 


\section{Podsumowanie}

Zakaz dyskryminacji w zatrudnieniu ze względu na niepełnosprawność pojawiający się W systemie prawa międzynarodowego, wspólnotowego i krajowego z pewnością przyczynił się do wyrównywania szans. Jak najbardziej pozytywnie należy ocenić działalność różnych organizacji na rzecz osób niepełnosprawnych, wśród nich można wymienić Fundację Aktywizacja oraz Polską Organizację Pracodawców Osób Niepełnosprawnych, która organizuje konkurs „Lodołamacze”. Na aprobatę zasługuje także organizowanie targów pracy dla osób niepełnosprawnych przez władze samorządowe. Niepełnosprawność nie oznacza braku odpowiedzialnej postawy w miejscu pracy, wręcz przeciwnie, wydaje się, że taka osoba będzie jeszcze bardziej zaangażowana i doceni fakt, że udało się jej zdobyć pracę. Jeżeli zatrudnianie osób niepełnosprawnych nie wynika $\mathrm{z}$ dobrej woli albo z poczucia misji, to pracodawca powinien zdecydować się na taki krok, kierując się rachunkiem ekonomicznym $^{46}$. Zatrudnianie osób niepełnosprawnych jest dla pracodawcy korzystne, ponieważ dzięki temu przysługuje dofinansowanie wynagrodzeń pracowników niepełnosprawnych, refundacja składek ZUS, zwrot kosztów na przystosowanie stanowiska pracy i wiele innych ${ }^{47}$.

\section{Bibliografia:}

\section{Literatura}

Czyżewska A., Zasada równego traktowania a zakaz dyskryminacji - w jaki sposób odpowiada pracodawca?, maj 2011, http://biuletyn.piszcz.pl/prawo-pracy/41-anna-czyewska/266-zasadarownego-traktowania-a-zakaz-dyskryminacji-w-jaki-sposob-odpowiada-pracodawca137 Florek L., Europejskie prawo pracy, Warszawa 2007

Gersdorf M., Raczkowski M., Rączka K., Kodeks pracy. Komentarz, Warszawa 2014 Góral Z., O kodeksowym katalogu zasad indywidualnego prawa pracy, Warszawa 2011 Grzonka L., Zatrudnianie osób niepetnosprawnych, Warszawa 2010, Jan Paweł II, Laborem exercens. Tekst i komentarze, red. J. Gałkowski, Lublin 1986 Jankowska M., Prawa osób niepetnosprawnych $w$ międzynarodowych aktach prawnych, http://www.pfron.org.pl/kn/poprzednie-numery/68, Prawa-osob-niepelnosprawnych-wmiedzynarodowych-aktach-prawnych-The-rights-of-di.html Jaśkowski K., Kodeks pracy. Komentarz, T. I, Warszawa 2014

Latos-Miłkowska M., Ochrona trwałości stosunku pracy pracowników niepetnosprawnych i opiekunów osób niepetnosprawnych, w: Zatrudnianie osób niepetnosprawnych. Regulacje prawne, red. A. Giedrewicz-Niewińska, M. Szabłowska-Juckiewicz, Warszawa 2014

\footnotetext{
46 K. Olszowska, Zatrudnianie niepetnosprawnych- co zyskuja pracodawcy?, 09.09.2014, http://www.rynekpracy.pl/artykul.php/wpis.822 (dostęp: 25.05.2015).

47 L. Grzonka, Zatrudnianie osób niepetnosprawnych, Warszawa 2010, s. 50-64. Autor opisuje m. in. dofinansowanie do adaptacji pomieszczeń, dofinansowanie szkoleń pracowników niepełnosprawnych, zwrot kosztów wyposażenia stanowiska pracy.
} 
Matey-Tyrowicz M, Zakaz dyskryminacji w zatrudnieniu w prawie wspólnotowym, w: Prawo pracy a wyzwania XXI wieku: księga jubileuszowa Profesora Tadeusza Zielińskiego, red. M. MateyTyrowicz, L. Nowacki, B. Wagnar, Warszawa 2012

Olszowska K., Zatrudnianie niepetnosprawnych - co zyskuja pracodawcy?, 09.09.2014, http://www.rynekpracy.pl/artykul.php/wpis.822

Radziwon I., Orzekanie o niepetnosprawności oraz o jej stopniu, w: Zatrudnianie osób niepetnosprawnych. Regulacje prawne, red. A. Giedrewicz-Niewińska, M. Szabłowska-Juckiewicz, Warszawa 2014

Romer M. T., Kodeks pracy. Komentarz, Warszawa 2012

Sobczyk A., Kodeks pracy. Komentarz, Warszawa 2014

Szewczyk H., Glosa do wyroku SN z dnia 2 października 2012 r., II PK 82/12

Szymczak M., Stownik języka polskiego, T. 1, A-K, Warszawa 1993

Świątkowski A. M., Kodeks pracy. Komentarz, Warszawa 2012

R. Whittle, The Framework Directive for equal treatment in employment and occupation: an analysis from diability rights prospective, http://shura.shu.ac.uk/706/1/fulltext.pdf

Winiarska A, W. Klaus, Dyskryminacja i nierówne traktowanie, „Studia BAS” 2011, Nr 2

\section{Orzecznictwo}

Wyrok Trybunału Konstytucyjnego z dnia 16 grudnia 1997 r., $\quad$ K $\quad 8 / 97$, http://orka.sejm.gov.pl/proc3.nsf/opisy/173.htm

Wyrok Sądu Najwyższego z dnia 24 marca 2000 r., I PKN 314/99, LEX nr 48110

Wyrok Naczelnego Sądu Administracyjnego z dnia 12 maja 2000 r., II SA 143/00, Legalis nr 48819

Wyrok Sąd Najwyższego z dnia 26 marca 2002 r., I PKN 57/01, LEX 563989

Wyrok Europejskiego Trybunału Sprawiedliwości z dnia 11 lipca 2006 r. C-13/05, LEX 226783

Wyrok Sądu Najwyższego z dnia 4 stycznia 2008 r., I PK 188/07, LEX nr 442864

Wyrok Sądu Najwyższego z dnia 12 kwietnia 2012 r., II PK 218/11, LEX nr 1313656

Wyrok Sądu Najwyższego z dnia 2 października 2012 r., II PK 82/12, Orzecznictwo Sądów Polskich, Warszawa 2014, z. 11, s. 1494-1503

Wyrok Sądu Apelacyjnego w Szczecinie z dnia 17 lipca 2013 r., III AUa 157/13, LEX 1438160

Wyrok Sądu Najwyższego z dnia 12 listopada 2014 r. I PK 74/14, LEX nr 1567458 